\title{
Orhan Pamuk and the East-West Dichotomy
}

\author{
EMILIA PARPALĂ, RIMONA AFANA
}

\begin{abstract}
The paper focuses on the manner in which O. Pamuk deconstructs the East-West dichotomy in his allegoric novel My Name is Red. We consider that the following isotopies are relevant for the interface between literature and the postmodern discourse on interculturalism and transculturation: (a) dialogism and indirectness (Pamuk replaced Eco's semiotic theme with an identity theme, thus suggesting a retrospective reading of The Name of the Rose as a novel of European Christian identity); (b) the liminality of the chronotop (the decline of the Ottoman power, Istanbul as a transitional and cosmopolitan space); (c) the issue of style: miniature vs. portrait (the theocentric Islamic art vs. the anthropocentric Western art); (d) the polyphonic enunciation (Pamuk practises a literature of view points, a combination of Eastern and Western styles). Detrimental to political theories, the Turkish Nobel Prize winner pleads for an authentic personal and national identity, for the need for keeping the integrity through synthesis, tolerance, faith and self-consciousness.
\end{abstract}

Keywords: enunciation, identity, miniature, portrait, My Name is Red, Orhan Pamuk, transculturation.

DOI: http://dx.doi.org/10.12697/IL.2013.18.1.03

\section{Preliminary remarks}

Orhan Pamuk was awarded the Nobel Prize in Literature in 2006. Explaining their choice, the Swedish Academy emphasized the intercultural collision and fusion, emerging from Istanbul's ambivalent location: "In the quest for the melancholic soul of his native city, [Pamuk] has discovered new symbols for the clash and interlacing of cultures".

The hypothesis of this research consists in the observation that the implicit discourse - the medieval allegory, the signs, the visual codes, the postmodern and postcolonial concepts which the Turkish novelist resorts to in My Name is Red (Benim Adım Kirmızı, 1998) - are means of discrediting some current hegemonic discourses associated with globalization: the problems of the modern world in general and of Turkey in particular. Consequently, postmodern 
concepts such as closure vs. opening, identity vs. otherness, difference, liminality, hybridity, and double consciousness are being used as filters in our interpretation. The methodological background includes semiotics, stylistics and cultural studies. The paper focuses on the East-West dialectics, in the light of the novel's narrative rhetoric and of paratextual information delivered by Pamuk himself.

As a major authorial theme, the East-West dichotomy, a concept of geopolitical, sociological and cultural signification, was treated by Pamuk in a deconstructivist manner. Although the Turkish novelist does not write political novels, he questions the explanatory power of current theories in political science or in cultural studies, and offers answers to the global politics of interculturalism and transculturation ${ }^{1}$.

In line with Edward Said's “orientalism”2, Pamuk's vision of Turkey's modernity offers a less radical model of globalization than that proposed by Huntington's "clash of civilizations" 3 . In order to transcend the modern dichotomies, Pamuk dramatizes "the eastness of the East and the westerness of the West"; he warns us: "let me point out, that I don't believe in this clash, although it's happening. And in my novels I try to say: all generalizations about East and West are generalizations. Don't believe them, don't buy them" (Farnsworth, interview 2002). Because he dislikes such disputed theories, the novelist

1 The term "transculturation" has been coined by the Cuban anthropologist Fernando Ortiz (1995 [1940]), referring to macro-social contexts, at inter- and multicultural level. In his opinion, the term better expresses the different phases of transition from one culture to another, because these are not limited to the acquisition of the new culture (processes designated by the term "acculturation"), but also refer to the loss of the former culture (processes designated by the term "deculturation"). In addition, "transculturation" contains the idea of creation of a new cultural phenomenon, which could be called "neoculturation". Transculturation is an aspect of global phenomena and reflects the natural tendency of human beings to solve conflicts, not to exacerbate them.

2 Mirror concepts such as "orientalism" (Said 1978), "balcanism" (Todorova 1997), "occidentalism" (Venn 2000), "Eastern/Central Europe” (Wolf 1994) denounce the Western hegemonic ideology. Pamuk, as Todorova, considers that the real difference between Islam and Christianity is not cultural by nature, but social, reducible to the difference between the poor and the rich. Although Turkey is an emblem of the Balkans, Pamuk is not interested in "balkanism", but in the East-West dichotomy.

3 According to Samuel Huntington's theory, the dominant source of conflict in the postCold War era will not be primarily ideological or economic but people's cultural and religious identities; the "clash of civilizations" (Islam vs. Christianity) will dominate global politics (Huntington 1996: 307; 321). Huntington's thesis has been criticized for viewing civilizations as fixed, monolithical entities (Edward Said) and for justifying the "atrocities" of the United States (Noam Chomsky). 
PARPALĂ, AFANA

considers that "what matters are not civilizations, but human lives" and that "good literature" helps us to perceive otherness as identity:

I've been saying to my readers that what is important is not clash of parties, civilizations, cultures, East and West, whatever. But think of that other peoples in other continents and civilizations are actually exactly like you and you can learn this through literature. Pay attention to good literature and novels, and do not believe in politicians; actually what matters are not civilizations but human lives, little things about daily life - little smells, colors, and atmosphere of daily life and little stories that we live. (Ib.)

In accord with postmodern epistemology, Pamuk transcodes the identity crisis of his country ${ }^{4}$ on the grounds of iconicity, in a fascinating story about painting and its impact on reality. My Name is Red is a parable about modern Turkey, which has to choose between staying an isolated power in the Middle East or adhering to the European Union; in the novel, this dilemma is built around the artistic conflict between two different ways of representing the world. One is that of seeing the world through God's eyes or with the mind's eye, as the Islamic miniature painters did. The other is of seeing the world through the eyes of any individual person: the Frankish/Venetian art of portraiture. The breaking point of the canon is allegorically represented in My Name is Red on the symbolic ground of visual artistic styles. Thus style becomes the basic isotopy of the text and the stake of the East-West hybridization.

\section{Dialogism and indirectness}

My Name Is Red is a postmodern novel build-up on the dialogical and architectonic principles, intertextually related to pluricoded sources. Pamuk is an intellectual of double consciousness, an empathic observer of both traditional Eastern literature and European modern authors. He has confessed that behind his novel there are authors to whom he refers directly, parodically or by alluding: Umberto Eco (the pastiche of the title, the formula of the pseudo-detective novel with cultural motivation, the medieval atmosphere, the thematization of arts etc.); Italo Calvino (the semiotics of the town, the inventiveness and

\footnotetext{
4 Pamuk has criticized the way Turkey managed the East-West differences in the $20^{\text {th }}$ century; he holds that Kemal Atatürk, who ardently worked for his country's modernization, abolished elements of ethnic identity and separated the present from the past, especially by the adoption of the Latin alphabet.
} 
multiplication of points of view); J. L. Borges (the text as an intertext); Thomas Mann (the combination of details and the use of painting in order to explore the soul of his nation ${ }^{5}$ ); Stendhal (love as a unifying metaphor); Balzac (analytical descriptions); Dostoievski (the feeling of guilt and sin) and particularly Margaret Yourcenar, in regard to the tone and the language of her historical fictions. If the novel is the modern creation of the West, the Orient has fascinated him with the charm of the story tellers, with the fineness of Persian poetry and with the power of modern synthesis, such as Rushdie's.

Clearly, the central intertextuality refers to Eco's The Name of the Rose. Its echo in My Name is Red is synthesized by Shekure on the antepenultimate page: "Thus withered the red rose of the joy of painting and illumination that had bloomed for a century in Istanbul, nurtured by inspiration from the lands of Persia" (501). Unlike Eco's nominalism (not the rose, but its name ${ }^{6}$ ), Pamuk focuses on Red - the colour synonymous with life itself:

Behold how wonderful it is to live! Behold how wonderful to see. Behold: Living is seeing. I am everywhere. Life begins with me and returns to me. Have faith in what I tell you (226);

Thereby, as I bring my color to the page, it's as if I command the world to 'Be!' Yes, those who cannot see would deny it, but the truth is I can be found everywhere. (228)

Both novels are, at the seductive level of consumption, detective novels with cultural motivation. In The Name of the Rose the desired object is the secret manuscript of the second part of Aristotle's Poetics, the book about comedy, counterpart of the theory of tragedy. The four serial crimes take hold of the naive reader but, as the palimpsestic text is displayed, the number of competent readers diminishes; the encyclopedic competence supposed by Eco's novel is overwhelming ${ }^{7}$, so that a small number of "ideal" readers accesses the global

5 “Pamuk uses the art of miniature illumination much as Mann's Doctor Faustus did music, to explore his nation's soul" (Updike 2001).

6 The Name of the Rose ends with Adso's words: "I let this novel but I don't know for whom, I don't know for what anymore 'stat rosa pristina nomine, nomina nuda tenemus' 'Through its name the ancient rose lasts, but we keep only the name'." In an axiomatical way, C. S. Peirce formulated his famous principle: "All thought is in sign." As concerns the second term of the title, the rose with five petals refers to an ideal aesthetic principle.

7 For S. Marcus (2005: 147), The Name of the Rose is a demonstration, in a narrative key, of the semiotic theory elaborated by Eco and recommended to be read in parallel with A Theory of Semiotics, 1976. 
PARPALĂ, AFANA

signification ${ }^{8}$. In My Name Is Red two crimes are committed in order to defend the style of old miniature masters, threatened with the Western art of portrait. Semiotic and logical techniques of investigation are used in the first novel by Guglielmo and Adso, stylistic and intuitive in the second, by Osman and Black.

By writing atmosphere novels, the two authors rely on medieval and topographical exoticism. Eco brings the mystery of Christian and Latin Middle Ages to the reader in the image of an abbey in Northern Italy, in the autumn of 1327. The chronography, with its seven days, each subdivided according to liturgical hours, is a parody of the Genesis. Pamuk makes use of Oriental "exoticism", which is a romantic projection of the West. He recreates the cosmopolitan, crepuscular Ottoman Istanbul in the winter of 1591, under the reign of Sultan Murat III.

Eco specified that he wrote his novel "in a mental climate of great agitation", in 1968, when the Soviet troops were occupying Prague; in this context, his novel is a political parable for aggression and risk, the consequence of abandoning the rational principle. For Pamuk's allegory, the political connotations of East-West dichotomy have been discussed in our preliminary remarks.

On the other hand, the dramatic upheaval of situations "dialogizes" with essay-like insertions referring to epistemological, theological, aesthetic or identity subject matters. In both novels there is a philosophical level concerning the relation with transcendence defining medieval culture. Eco called this universal allegorism which prolongs the mytho-poetical activity of the archaic mentality and reads the world like a book "metaphysical semiosis". For Pamuk, the Islamic sacralization of the image brings about the encomium of blindness and memory: "Blindness is silence" (73); "Painting is the silence of thought and the music of sight" (72). While Jorge's blindness in The Name of the Rose is a metaphor of his dogmatic irrationality, the self-induced blindness of the famous Ottoman masters (Osman, Behzad) signifies the divine essence of miniature in the Islamic highly stylized art: "The deepest aspect of the picture is to see what is already seen in the God's darkness" (88); "painting is the act of seeking out Allah's memories and seeing the world as He sees the world" (96).

The aesthetic issues of syncretism and the relation between art and life are thematized in both novels. At the beginning of his novel, Eco warned: "A manuscript, of course, because it is a story about books, not about the daily miseries" (Eco 1983: 22). But is the labyrinthic library a mirror of the world? Shekure, Pamuk's heroine, expresses at the end of the novel the desire to have her portrait done in the technique of old Herat masters: "In actuality, we don't look for smiles in pictures of bliss, but rather, for the happiness in life itself.

\footnotetext{
8 A proper model of reading postmodern novels could be an upset pyramid.
} 
Painters know this, but this is precisely what they cannot depict. That's why they substitute the joy of seeing for the joy of life." (503)

Both novelists pay their respect to traditional culture, delving into issues such as the survival of identity symbols in contexts of crisis generated by the clash of mentalities or cultures. Eco proposes a world of reason, Pamuk - a world of imagination. Each introduces us to a specific culture, using two styles of representing the world: with mind and with eyes, whence the primacy of writing in Christianity, the primacy of image in Islam.

For delivering their view of the present, Eco and Pamuk rely on indirectness, making use of medieval allegories, of symbolic metonymies like manuscripts, portraiture and miniature, of iconic and indexical signs like style and signature and of sophisticated means of enunciation. The "recycling" performed by Pamuk consists in replacing Eco's semiotic theme with an identity theme (the deconstruction of the East-West opposition), symbol conversion, dialogism, polyphony. As we argued (Parpală 2008), the genotext (Eco’s novel), read from the perspective of the phenotext (Pamuk's novel), undergoes a semantic enrichment, turning implicitly into a novel of European Christian identity.

\section{The chronotop: liminality and loss}

Real, dreamt or "invisible" (Calvino 1972), the cities of the world feed the collective imagination with archetypal, utopian or political landmarks. Unlike the urban sociology ${ }^{9}$, the cultural discourse builds the big cities, strained by history, as "mind landscapes" (Corti 2000), as mental spaces. ${ }^{10}$ What Istanbul could mean in a symbolic reading of the world? The semiotics of towns, reflecting the dynamics of civilizations, supposes two dimensions: the town as a space and the town as a name. Byzantium, Constantinople and Istanbul - three names used to designate the palimpsestic capital of empires. It is an oxymoronic interface which unifies and separates two continents; in Turkish, Arabic, Persian and European literatures, this unique capital was present for centuries.

"In the quest for the melancholic soul of his native city", Pamuk favored Istanbul - a liminal, transitional and cosmopolitan space, where cultures face

9 Cf. the theories on urban development worked out by Max Weber, Walter Benjamin, the Chicago School, Ronald Daus, Saskia Sassen (Freitag 2003).

10 Thus: Babel - the infernal city, Jerusalem - the celestial city of Saint Augustine, Rome the eternal city, Constantinople - "the second Rome", Paris or Saint Petersburg - antagonistic places of double codification, Venice - archetype of the aquatic citadel, New York - the victorious "Babel”, Brasília - the utopian capital. 
PARPALĂ, AFANA

themselves (Islam vs. Christianity), thus gaining self-consciousness. The western edge of the East and the eastern limit of the West, Istanbul is a melting pot in which cultures fuse, in which a new synthesis, the school of miniature painting dreamt by the old master Osman, was not possible any more. The Turkish writer projects his native town as a place of antagonisms - failure and hope in which cold, fires, poorness, cruelty are counterparts of love, of the sultan's wealth and of the art's sublime. He suggests that the town could be conceived like a permeable text, like a labyrinth of visions and portraits.

The melancholy of Istanbul's inhabitants, caused by their living at crossroads, in a place of imperial ruins, in a country under modernization is called hüzun, an intranslatable Turkish word implying the feeling of a deep spiritual loss and simultaneously a hopeful way of seeing life. Pamuk writes: "What I am trying to explain is the hüzun of an entire city: of Istanbul". That is the collective melancholy of being divided. As John Updike (2001) remarked: "like his city and his country, Pamuk's works touch upon the dialectics of a double heritage". By thematizing his native city, Pamuk implies that complex cultural events are generated in points of fissure ${ }^{11}$, by disjunction of nations, places or time. This hybrid transcultural culture, revealing the power of mediation, is embodied in the metaphor of the Bosphorus bridges which divide and unite at the same time.

The novel's time is liminal too. The closing of Istanbul school of miniature painting, consecutive to adopting the Western art of portrait, style and perspective, connotes the decline of the Ottoman power. Five characters, foremost Sultan Murat III himself, are fascinated by the idea of an everlasting image and pine for their portraits: "Everybody secretly desires to have a style" said Black smartly. "Everybody also desires to have his portrait made, just as Our Sultan did" [...] "As this plague spreads, none of us will be able to stand against the methods of the Europeans" (483). The consequences of transculturation are violent: the realism defeats the dream, the pragmatic West will prevail, loss of identity is imminent in the East. Pamuk will be insisting on this message dedicating many pages to the portrait, as a symbol of self-consciousness, opposed to the miniature - miraculous, but well sealed into the canon.

11 Other symbols of liminality: the boundary (which separates only) and the threshold (which divides and connects simultaneously) (Werbner \& Madood 1997; Florea 2006). 
Orhan Pamuk and the East-West Dichotomy

The issue of style: miniature vs. portrait

The miniature and its endless time are, for Pamuk, what the library and its labyrinthine space have been with Eco. "What could be more exquisite than looking at the world's most beautiful pictures while trying to recollect God's vision of the World?" (394) asks Black, suggesting the homology between the human creation and the Creator's sight.

Although connected to western authors, the Turkish novelist promotes the distinctive character of his culture. Beyond its historical and aesthetical significance, the metaphysics of the iconic sign comprises two very distinct ways of viewing the world, accurately defined in his 2003 interview:

To be influenced by the western ways of portraiture is a dilemma for the traditional Islamic painter who is devoted to repetition and purification of traditional forms. Beyond this lie two different ways of seeing, painting and even representing the world. One is that of seeing the world through the eyes of any individual person - looking at things from our humble point of view. The other is seeing the world through God's eyes, from high above as the Islamic painters did, and perceiving the totality of, say a battle from above. The latter is more like seeing with the mind's eye, rather than the eye itself. (Knopf, interview 2003)

From the perspective of cultural typology, the expression of Islam is visual; as illustrated by "flying" books, whose pages composed other books, as the one in the story of the "fallen from the story" tree.

In its archaic syncretism, the miniature lives in symbiosis with the story and vice-versa: "[...] 'It is the story that's essential', our wisest and most Glorious Sultan had said. 'A beautiful illustration delicately completes the story [...]'." (132) Strongly rooted in the Herat style, the Istanbul school of miniature painting went through a moment of crisis, as a consequence of its exposure to Frankish and Venetian art of portraiture. The clash between East and West on the ground of painting codes (miniature vs. portraiture) opens a long and complicated discussion about style and "signature".

The old masters were practicing a style lacking style - a lack of inventiveness; from the anthropocentric perspective of the European man this is anonymity. In the East, the collective approach to style makes peculiar the style of the famous miniature schools from Herat, Shiraz, Tabriz, Bukhara, Samarkand, Istanbul: an art of meaning obtained by formal repetition. In the canonical art of miniature, the error is the index of (individual) style. Under the pretext 
PARPALĂ, AFANA

of searching for a horse with strange nostrils - the stylistic "signature" of the murderer, Osman and Black arrive at the Serai, the counterpart of Eco's library. For a few frosty days, the two of them celebrate the golden time of the image and of the story, two identity signs of Islamic spirituality.

The style the sultan's artists are surreptitiously instructed to adopt is that of the Italian Renaissance. Frankish novelty is represented by the brilliance of the Venetian death-defying art of portraiture. Figures are of specific people and these paintings are not illustrations: they stand as works of art in their own right. The centrality of the individual distinguishes the paintings of the Venetian masters from the miniaturists' devotion to "how God sees the world". The Western techniques were about perspective and point of view, whereas the traditional Islamic approach involves memory, an illustrated hierarchical world, a collective style. Miniature is an art of meaning and repetition, meanwhile the Renaissance portraiture is an art of form and invention. Through realism that reduces the world to the dimensions of the human gaze, which flatters the mortal with the illusion of immortality, through difference, portraiture seriously competes with the symbolic and poetic art of miniature. The two codes are presented as incompatible:

Believe me, none of the Venetian masters have your poetic sensibility, your conviction, your sensitivity, the purity and brightness of your colors, yet their paintings are more compelling because they more closely resemble life itself. They don't paint the world as seen from the balcony of a minaret, ignoring what they call perspective; they depict what's seen at street level, or from the inside of a prince's room, taking in his bed, quilt, desk, mirror, his tiger, his daughter and his coins. They include it all, as you know. I'm not persuaded by everything they do. Attempting to imitate the world directly through painting seems dishonorable to me. I resent it. But there's an undeniable allure to the paintings they make by those new methods. They depict what the eye sees just as the eye sees it. Indeed, they paint what they see, whereas we paint what we look at. Beholding their work, one comes to realize that the only way to have one's face immortalized is through the Frankish style [...] Just a glance at those paintings and you too would want to see yourself this way, you'd want to believe that you're different from all others, a unique, special and particular human being. Painting people, not as they are perceived by the mind, but as they are actually seen by the naked eye, painting in the new method, allows for this possibility. One day everyone will paint as they do. (205-206)

The use of painting to celebrate individuality and the human figure began to generate a new debate on the nature of painting among Islamic miniaturists. 
Some perceived this as a threat to the style and purity of traditional miniature painting. To portray individuals or objects for their own sake and without cover of words was to give them iconic standing. Since the Sultan himself wanted his portrait to be made, the world of the miniature could not survive. The supreme taboo of the "sacred" Quran, the portrait is a devilish blasphemy because it substitutes anthropocentrism and human creativity (with laic, European origins) for theocentricity and stylistic anonymity. These western artists (Frankish and Venetian masters) do not render the essence of what they are painting - for instance, the idea of the perfect tree - but rather a likeness of the thing itself. The perspectival shift of representational art lowers the central focal point to the level of the artist himself, not as Allah would see it from heavens. This is considered a heresy, a blasphemy and a deadly sin. An individual or western style of painting might threaten this ideal of timelessness or blindness:

He said unfortunate Enishte had brazenly used the perspectival method in the last picture. In this picture, objects weren't depicted according to their importance in Allah's mind, but as they appeared to the naked eye - the way the Franks painted. This was the first transgression. The second was depicting Our Sultan, the Caliph of Islam, the same size as a dog. The third transgression also involved rendering Sultan the same size, and in an endearing light. But what surpassed them all - a natural result of introducing this Frankish understanding into our paintings - was drawing Our Sultan's picture as large as life and his face in all its detail! Just like the idolators do... Or just like the 'portraits' that Christians, who couldn't save themselves from their inherent idolatrous tendencies, painted upon their church walls and worshiped. Elegant Effendi, who learned of portraits from your Enishte, knew this quite well, and believed correctly that portraiture was the greatest of sins, and would be the downfall of Muslim painting. (476-477)

The "fundamentalist" hero, the Killer/Olive argues that the secularization of the Islamic painting would symbolically determine the loss of meaning: "this entire universe of meaning will end and the universe of form will begin" (448). In the intercultural dialogue, the style is an index of collective/individual identity, thus mimicry is considered to be a suicide of identity: "Had Enishte Effendi's book been completed and sent to them, the Venetian masters would've smirked, and their ridicule would've reached the Venetian Doge - that is all. They'd have quipped that the Ottomans have given up being Ottomans and would no longer fear us." (487) 
PARPALĂ, AFANA

Pamuk implies that the violence results from divided selves (the murderer says that he is "completely divided"), from division between the East and West, between blindness and sight; he insists upon the consequences of this turning point: "So from this single, all embracing, medieval or Islamic point of view, transition to a multi-voiced, multi-perspective, rich, western point of view [...] is full of agony. That means leaving aside a whole tradition, a whole way of seeing things." (Farnsworth, interview 2002) The death of miniature is a transparent metaphor for Turkey's hasty westernization and gradual abandoning of tradition(s).

After adopting the Frankish art of portraiture the "red rose" of miniature withered and "no one behaved as though abandoning illustration were any great loss. Perhaps because nobody had ever seen his own face done justice on the page" (502) - explains Shekure. By submitting to the Islamic taboo, the individual has achieved neither knowledge nor self-consciousness.

The Turkish postmodern novelist highlights the role played by the symbolic hybrids in the construction of multi-cultural identities based on "impurity" (Scarpetta 1985), transgression of boundaries, double-consciousness. "Nothing is pure" said Enishte Efendi:

In the realm of book arts, whenever a masterpiece is made, whenever a splendid picture makes my eyes water out of joy and causes a chill to run down my spine, I can be certain of the following: Two styles heretofore never brought together have come together to create something new and wondrous. (194)

The polyphonic enunciation

My Name Is Red is a vast postmodern narrative, made up of 59 chapters with 20 narrative voices such as the Red, the Money, the Horse, the Dog, the Tree, the Ink, the Corpse, the Death, personifying ubiquitous life. Instead of creating the realistic illusion that art is life, Pamuk (like Eco) emphasizes the ontology of the novel, its insertion in life as an artifact which creates order and significance in competition with the chaotic complexity of life. The polyphonic enunciation embodies the reversible metaphors EXISTENCE AS A TEXT and TEXT AS A TEXTURE OF EXISTENCES.

Pamuk practices a literature of viewpoints, his aim being to point out the omnipresence of meaning, rather than to emphasize its relativization. In the novel these alternative voices mirror each other, they reciprocally comment, 
sustain and modify the general context. My Name Is Red is a "palace of echoes", as long as the universe is imagined as a palace with countless rooms. Hence, the narrative voices support each other, telling what they know that the others do not. Fascinated by perspective and subjectivity, Pamuk writes a first-person narrative seen as if through a prism, ceaselessly reiterating the same idea. At the end of the story, Pamuk quotes two familiar tropes recurrent in Islamic literature: the author's signature ${ }^{12}$ and the narrator's lie $^{13}$. Shekure transmits the story to her son, Orhan, but we should not believe all he is saying, because the tellers are liers: "In the hopes that he might pen this story, which is beyond depiction, I've told it to my son Orhan. [...] For the sake of a delightful and convincing story, there isn't a lie Orhan wouldn't deign to tell." (503)

Pamuk reveals himself as an artist of double consciousness who embraces not only the dreamy Orient but also the agitated West; he insists that his novels are the reflex of his hybrid identity, a combination of Eastern and Western styles. From a stylistic point of view, the Turkish novelist is a synthetic author of original formula:

The formula I use in my writing is a combination of postmodernist narrative techniques with Turkish traditional literature. In My Name Is Red, I tried my best to combine these two to write an experimental, modern, European novel. My formula for writing a novel is this: try to combine two different things that have never been put together before, and do this stylistically. (Farnsworth, interview 2002)

My Name Is Red is also a novel on style and signature, a refined intertextual palimpsest displaying an inimitable polyphony.

\section{Closing remarks}

Pamuk projects himself as an interface, as a builder of bridges between Islam and the West; he considers the bridge a metaphor for himself as an observer: "I want to be a bridge in the sense that a bridge doesn't belong to any continent, doesn't belong to any civilization, and a bridge has the unique opportunity to

12 The last word in Khosrov and Shirin, the poem which inspired Black and Shekure's love story is the name of the author, Nezami.

13 In Golestan, Sa' di recommends himself as a traveler but warns us not to believe the travelers, because they tell lies. We have to remind that Eco (1975) defined semiotics as a "theory of lie": it studies everything that could be taken for a sign. 
PARPALĂ, AFANA

see both civilizations and be outside of it. That's a good, wonderful privilege." (Ib.)

As a parable, My Name Is Red is the answer of a Turkish intellectual to the global challenges of transculturality; symbolic metaphors as God, miniature, love, the Red are crossing the divisions and remake the whole in a similar way Islamic art brings everything to the forefront, without gradation or perspective. The kind of literature he is practicing and defending in his meta-texts ${ }^{14}$ opens an intercultural space of mutual knowledge and "cultural symbiosis" (Talvet 2005).

The closure of knowledge is self-destructive, Eco suggested through Jorge's parable. The immature, imprudent opening to otherness is dangerous to identity, suggests Pamuk through the portraiture's parable. The message conveyed refers to the imperative of becoming conscious, as individuals who have seen their "portrait" - and thus acquired self-awareness - of traditions' value, of our identity symbols, aware of a lucid participation in the intercultural dialogue, of working with a flexible reason and of putting ourselves under the unifying sign of transcendence: "To God belong the East and the West" (this is a verse from Quran quoted as a motto of the novel). Through Uncle's voice, Pamuk deconstructs the postmodern dichotomies borrowed from The Name of the Rose, pleading for the need of preserving integrity through synthesis, tolerance, faith and... impurity: "May He protect us from the will of the pure and unadulterated" (194).

\author{
Emilia Parpală, Rimona Afana \\ parpala_afana@yahoo.com \\ Str. Spania, bl. O10, ap. 3 \\ Craiova \\ Dolj 200504 \\ ROMANIA
}

\footnotetext{
14 "I tried to tell my story in the manner of these Persian masters. These two distinctive ways of seeing the world and narrating stories are of course related to our cultures, histories, and what is now popularly called identities. How much are they in conflict? In my novel they even kill each other because of this conflict between east and west. But, of course, the reader, I hope, realizes that I do not believe in this conflict. All good art comes from mixing things from different roots and cultures, and I hope My Name is Red illustrates just that." (Ib.)
} 
Orhan Pamuk and the East-West Dichotomy

\section{Bibliography}

Calvino, I. 1972. Le città invisibili. Torino: Giulio Einaudi Editore.

Corti, M. 2000. Pentru o enciclopedie a comunicării literare. [Şt. Mincu, transl.] Constanța: Pontica.

Eco, U. 1975. Trattato di semiotica generale. Milano: Bompiani.

Eco, U. 1983 [1980]. The name of the Rose. [W. Weaver, transl.] Harcourt, Inc.

Eder, R. 2001. Heresies of the Paintbrush. - New York Times Book Review, 02.09, 7.

Farnsworth, E. 2002. Bridging Two Worlds. - The News Hour, MacNeil/Lehrer Productions, 1-6, http://www.pbs.org/newshour/conversation/july-dec02/ pamuk_11-20.html.

Florea, S. 2006. Intercultural Communication: on Cultural Liminality and the Loss of Self. - Annals of the University of Craiova, Series: Philology-English, 1, 170-178.

Freitag, B. 2003. Global Cities in Informational Societes. - Diogenes, 50, 1, 71-82.

Huntington, S. P. 1996. The Clash of Civilizations and the Remaking of World Order. Simon \& Schuster.

Levi, J. 2001. Culture clash. - The Guardian, 15.09.

Knopf, A. A. 2003. A Conversation with Orhan Pamuk. The Borzoi Reader Online. Random House, 1-3, http://www.randomhouse.com/knopf/authors/pamuk/ qna.html

Marcus. S. 2005. Întâlnirea extremelor. Piteşti: Paralela 45.

Ortiz, F. 1995 [1940]. Cuban Counterpoint: Tobacco and Sugar. [H. de Onís, transl.] Durham, NC: Duke University Press.

Pamuk, O. 2001 [1998]. My Name Is Red. [E. Güknar, transl.] Shuster and Shuster.

Parpală, E. 2008. “The retaliation” of the Phenotext: Reading Umberto Eco's “The Name of the Rose" through Orhan Pamuk's "My Name is Red". - Annals of the University of Craiova, Series: Philology-English, 2, 219-228.

Ricoeur, P. 1990. Soi-même comme un autre. Paris: Seuil.

Said, E. W. 1978. Orientalism. London and Henley: Routledge and Kegan Paul.

Scarpetta, G. 1985. L'impureté. Paris: Grasset.

Talvet, J. 2005. A Call for Cultural Symbiosis. [H. L. Hix, transl.] Toronto: Guenica.

Todorova, M. 1997. Imagining the Balkans. New York: Oxford University Press.

Updike, J. 2001. Murder in miniature. A sixteenth-century detective story explores the soul of Turkey. - New Yorker, 03.09, 92.

Venn, C. 2000. Occidentalism. London: Sage Publications.

Werbner, P., Madood, T., eds. 1997. Debating Cultural Hybridity: Multi-cultural Identities and Politics of Anti-rasism. London and New Jersey: Zed Books.

Wolf, L. 1994. Inventing Eastern Europe - The Map of Civilization on the Mind of the Enlightment. Stanford: Stanford University Press. 